\title{
South Korea's Nuclear Power Phase-Out and the Role of Media
}

\section{Eun Ah Hong \\ University of Hawai'i at Manoa, United States and Universitat Jaume I, España}

$\left(\begin{array}{l}\text { Fecha de recepción: } 30 \text { de noviembre de } 2020 \\ \text { Fecha de aprobación: } 2 \text { de febrero de } 2021\end{array}\right)$

DOI: http://dx.doi.org/10.15304/ricd.3.14.7289

\section{NOTAS BIOGRÁFICAS}

Eun Ah Hong is student in international peace, conflict, and development studies at Universitat Jaume I (UJI) (Castellon, Spain). She received a bachelor's degree in anthropology from the University of Hawai'i at Manoa, and a master's degree in international peace, conflict, and development studies from UJI. Her research interest is social-environmental conflict, sustainable development, and environmental justice.

Contacto: heunah@yahoo.com

\section{Abstract}

South Korea is a resource-poor country, which heavily relied on importing energy from abroad. Therefore, the South Korean government decided to develop the technology necessary to produce nuclear power energy and succeeded in the 90s. Furthermore, thanks to the technological advancements of generating nuclear power, in 2009, the government gained a contract to build nuclear power plants in the United Arab Emirates. Since then, in South Korea, nuclear power energy has been considered a major factor of economic growth for the country's future. However, there were multiple social-environmental conflicts related to using nuclear power energy. Furthermore, with the 'unexpected' Fukushima Daiichi nuclear disaster in 2011, the nuclear power phase-out debate was initiated in South Korea. As a consequence, nuclear power phase-out was included in the energy transition policy when the newly elected government took presidential office in May 2017. In fact, the nuclear phase-out was a presidential pledge during the presidential election. However, this policy of nuclear power phase-out became one of the most intense social-political conflicts of the society, and the mass media played a key role in intensifying the conflict. In this regard, this article critically exposes how the issue of nuclear power was framed by the media, but more importantly proposes a new way of practicing journalism, which is peace journalism. For that matter, the author mostly relied on an analysis based on secondary resources, especially including the specific dissertation that well investigates the use of news frame over the issue of nuclear power phase-out, but also various academic journals, news, and information from different websites.

\section{Keywords}

Nuclear Power, Nuclear Phase-Out, Mass Media, South Korea, Peace Journalism. 


\section{ARTÍCULOS}

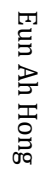

\section{Summary}

1. Introduction

2. Background: South Korea's Nuclear Power Phase-Out

3. Nuclear Power Phase-Out \& the Role od Mass Media

4. Peace Journalism as an alternative to transform polatization

5. Conclusion 


\section{INTRODUCTION}

No one can avoid framing as "every word is defined through the frames it neutrally activates" (Lakoff, 2010, p. 71). Thus, no word makes sense without the framing process because every talking and thinking involves the framing process. The framing process indeed helps us to understand stories by highlighting what is inside the frame (Canning \& Reinsborough, 2009). However, it also means that the stories outside of the frame can be easily ignored. Accordingly, as Lakoff $(2010$, p. 72) explores, the question of "whose frames are being activated-and hence strengthened-in the brains of the public" is necessary to be posed. In relation to that, it helps to explore Foucault's power-knowledge relations that explains how to produce particular 'truth':

We should admit rather that power produces knowledge (and not simply by encouraging it because it serves power or by applying it because it is useful); that power and knowledge directly imply one another; that there is no power relation without the correlative constitution of a field of knowledge, nor any knowledge that does not presuppose and constitute at the same time power relations. (Foucault, 1995, p. 27).

To sum up, shaping a perspective (or worldview/narrative) within a certain frame, which helps us to understand reality, is influenced by the power-knowledge relations. In other words, the reframing process is challenging since framing is "fundamentally about the issue of power in the story" (Canning \& Reinsborough, 2009, p. $20)$. And, the media plays a significant role in shaping social issues in certain frames.

However, for the traditional journalism practice, the world is considered as "a set of readymade facts" whereas "building up process and meaning are often ignored, or excessively simplified" (De Michelis, 2018, p. 2). In fact, the media is seen as an effective tool or door to inform the "social truths, operating within the context of a professional code that values 'objectivity', 'balance' and the 'public interest'” (Hobbs, 2008, p. 11). However, in daily journalism practices, many pieces of news and articles do not meet these requirements of objectivity, balance, or the public interest. Instead, the media seems to produce "norms into all forms of cultural production" (Galtung \& Lynch, 2010, p. 29) by providing 'objective' information. This means that journalists have "the power to 'make truth' particular regimes of truth" (Hobbs, 2008, p. 12). Consequently, there are many scholars criticizing mass media as "fuels" to intensify conflicts while damaging the peace-process (Ciftcioglu \& Shaw, 2020, p. 2).

For that matter, practicing peace journalism could be a helpful tool since peace journalism "uses the insights of conflict analysis and transformation to update the concepts of balance, fairness and accuracy in reporting" (Youngblood, 2017). Peace journalism indeed explores to provide "a new road map tracing the connections between journalists, their sources, the stories they cover and the consequences of their journalism, and builds an awareness of nonviolence and creativity into the practical job of everyday editing and reporting" (Youngblood, 2017).

Following that, in this article, the author examines how South Korea's nuclear power phaseout debate has been framed by the news media. Thereby, the article demonstrates how mass media have represented the issue of nuclear power phase-out, but also observes the role of media that unfortunately worsened the conflict over nuclear power phase-out in South Korea. Given that, the author proposes peace journalism as an alternative approach/practice for the media in South Korea.

The author mainly uses secondary sources, especially including the specific thesis "A study on the news frame about the issues of the social conflicts: focused on the 'nuclear-exit' policy of the Moon Jae-In government" by Ji-Ju Kim. It is because the dissertation presents a well-researched analysis of the use of news frames over the nuclear power phase-out issue. Other than that, other secondary sources, including academic journals, news, and different information published on digital platforms are also used to critically examine the media and the power that the media can practice.

\section{BACKGROUND: SOUTH KOREA'S NUCLEAR POWER PHASE-OUT}

South Korea is one of the top energy import countries in the world as the nation's energy consumption mostly relies on imports (e.g., in 2017 energy import dependence was 94 percent) (Korea Energy Agency, 2019). Therefore, for a resource-poor country, South Korea, stabilizing energy supply has been exceptionally important since it is one of the main requirements for successful economic development.

Accordingly, since the 1950s, South Korea has not only planned to produce nuclear power energy but also intended to develop the 
technologies of producing nuclear power energy on its own. Nuclear power energy was seen as dream energy that is 'cheap' and 'safe', and it was an attractive option for South Korea, which suffered under the energy shortage especially after the Korean War (1950-1953) as most of the energy facilities were located in North Korea. Consequently, South Korea became the 21st country to produce nuclear power energy in 1978 , but the nation further developed nuclear power technology in the 1990s (Yang, Lee \& Kim, 2015). Due to that, the dependency on nuclear power energy has increased, and currently (in November 2020) there are a total of 24 nuclear energy reactors in South Korea.

Besides, as climate change has become one of the most important agendas of world politics, a number of experts have argued that nuclear power energy could be the most 'realistic' alternative since it helps to reduce emissions but also to provide a stable energy supply. For instance, in South Korea, the previous president of KNF (Korea electric power corporation Nuclear Fuel), Sang-lk Lee, contends that nuclear power energy is a basis to build the country's economy as it provides 'cheap' but good quality of electricity, which, meanwhile, prevents producing green-house gases (Lee, 2018). In fact, such a view is a popular opinion in South Korea where nuclear power energy even became a leading business for the country's future economy, especially after winning a contract to build four nuclear power plants in the United Arab Emirates in 2009.

However, nuclear power energy inevitably contains the possibility of a catastrophic accident as it has proven through the Chernobyl and Fukushima Daiichi nuclear disaster. In this perspective, considering nuclear power energy as an 'affordable' resource can be polemical. If the risk cost of a possible disaster is included, it cannot be considered affordable as some argue, but more importantly, it is unbearable to convert all the damages caused by the nuclear disaster into monetary value. On that account, nuclear power energy use has become one of the most controversial topics in the world, especially after the Fukushima Daiichi nuclear disaster that occurred in Japan in 2011.

In South Korea, there have been various social-environmental conflicts caused by using nuclear power energy (e.g., conflict over constructing nuclear power reactors, transmission towers and lines, or radioactive waste disposal facilities). However, the issue of nuclear power energy use has become a public concern only after the disaster in Fukushima. And, 'unexpected/unusual' earthquakes (e.g., Gyeongju earthquake magnitude 5.8 in 2016, Pohang earthquake magnitude 5.4 in 2017) occurred in the south-east part of South Korea where most of the nuclear power reactors are located, definitely alarmed Korean society with nuclear power energy use.

Following that, many countries decided to shut down nuclear reactors (e.g., Germany), and South Korea also decided to reduce the energy dependency on nuclear power energy while increasing renewable energy resources. Accordingly, the new government of President Jae-In Moon who was elected in May 2017 officially proposed the energy transition policy, which was one of Moon's campaign pledges during the presidential election. In detail, the policy planned to gradually reduce the nuclear power reactors to 14 in 2038 (from 24 in 2017 to 28 in 2022 to 18 in 2031), whereas the renewable energy sources are planned to be increased up to 20 percent by 2030 from 7 percent in 2017 (Energy Transition Policy, 2020).

However, as the counter-argument against the government's new policy has been growing stronger, this new policy leads to a new socialpolitical conflict in Korean society.

\section{NUCLEAR POWER PHASE-OUT \& THE ROLE OF MASS MEDIA}

There are wide information and data about the issue of nuclear power phase-out. Among many, the main debate of the issue can be summarized followingly, economy vs. environment. Interestingly, both pro-and anti- nuclear energy groups set a high value on both economic benefit and environmental safety. However, they use different approaches to interpret and measure economic benefit and environmental safety.

The role of the media is critical. The media is the main news source for the majority of the public to understand the complex social-political issue as well as to further help them to make a decision. Especially for the issues that require complex professional knowledge (e.g., nuclear phase-out), the role of the media is even more important than usual. Nevertheless, in this particular case, unfortunately, most news articles rather produce fragment news frames that strongly demonstrate political partisanship.

The dissertation, "A Study on the News Frame about the Issues of the Social Conflicts: focused 
on the 'Nuclear-Exit' Policy of the Moon Jae-in Government" conducted by Ji-Ju Kim (2019), presents well how two major Korean newspapers framed the issue of nuclear power phase-out. In the research, Kim examines the characteristics of news frames applied by two major newspapers, which include Chosun (representing the conservative media) and Hankyoreh (representing the progressive media). For that, Kim used a total of 897 news articles, which contains 656 news articles from Chosun and 241 news articles from Hankyoreh from May 10, 2017 (when the President assumed office) to April 30, 2019.

According to the dissertation, the most mentioned issue with a nuclear power phase-out is the economic concern from both conservative and progressive media. However, each media's main emphasis on the issue is very distinctive. In the case of Chosun, the cost of energy transition $(47.2 \%)$ and industry's future competitiveness $(52.8 \%)$ were the most emphasized issues. Meanwhile, Hankyoreh mainly highlighted the cost of maintenance of nuclear power plants $(56.1 \%)$ rather than mentioning the cost of energy transition (21.1\%) and industry's future competitiveness (22.8\%).

In the case of environmental concerns, the same pattern is observed. Both media discuss the issue of environmental safety but with different emphases. While Hankyoreh highlights the issue of safety and environmental concern of using nuclear power (15.4\%), Chosun uses the same frame to expose the environmental conflict and cost caused by renewable energy resources or to emphasize that using nuclear power energy is safe (11.4\%).

In fact, the second most used frame for Chosun is condemning or criticizing the issue of a nuclear power phase-out (18.5\%), which is twice more than Hankyoreh. This means that news frames, especially from Chosun, seemingly used to 'rationally' attack/blame its 'opponent' rather than providing balanced information for the citizens to carry a discussion and make a reasonable decision. Kim accordingly demonstrates that the news from Chosun mainly criticizes the president and government officials, whereas the news from Hankyoreh mostly targets the members of the opposition party and conservative media that supports pro-nuclear power energy.

Therefore, the research conducted by Kim indicates that the issue of nuclear power phaseout became completely politicized. The opposition's party often uses the issue of nuclear power phase-out to attack the current government by using conservative mass media. In other words, the media does not seem to play its role of 'objectively' delivering the reality. As most media are producing news articles under a limited frame, it is challenging to see the deeper and wider discussion of the topic. There is often not enough space to present different perspectives. For instance, the conservative media (re) produces/strengthens already existing 'truth' that nuclear power energy is the most 'realistic' alternative to avoid climate change but also to provide a stable power supply required by the nation.

In the case of treating nuclear power energy as a 'cheap' resource, there is various research that shows different data/information to explain why it is cheap in South Korea. The South Korean government provides unconditional support and favors for the nuclear power energy industry. For that, in the scenario of a nuclear disaster, the entrepreneur is only charged up to 500 billion won (about 448 million dollars), which means that the rest of the fee for cleaning up the mess is covered by the tax (Kim, 2020). Besides, for the same size of the nuclear power energy facility, the yearly insurance premium in South Korea is only 10 billion won (about 8.9 million dollars) while it will cost 2.5 trillion won (about 2.2 billion dollars) in the U.S (Kim, 2020).

Hence, the pattern of the newspapers in the case of nuclear phase-out is accordingly polarized. Most of the conservative media produce news articles that attack the policy of nuclear power phase-out and the progressive media defend what has been attacked.

Several scholars criticize the role of mass media as it is often obsessed with conflict-oriented stories while emphasizing "bias in favor of event over process; a bias in favor of official sources and a bias in favor of dualism [two party reporting]" (Ciftcioglu \& Shaw, 2020, p. 4). For that matter, some say that news is not "a mirror of reality" but more of a selected representation (Schudson, 2003, p. 3). However, in other words, this means that mass media can represent the reality otherwise, for instance, under the guidance of peace journalism.

\section{PEACE JOURNALISM AS AN ALTERNATIVE TO TRANSFORM POLARIZATION}

Peace journalism, for the first time, was introduced by the Norwegian peace scholar Johan Galtung, and the idea/theory of peace journalism 
was developed by formal journalists Jake Lynch and Annabel McGoldrick (Ciftcioglu, 2017). Accordingly, peace journalism has been practiced worldwide, but also more scholars have been engaged in developing the theory. Thus, even though peace journalism was originally conceived with war reporting, peace journalism can be further applied in different kinds of daily journalism in order to build a more peaceful society.

To understand peace journalism, at first, it is necessary to understand what peace is. Peace was traditionally considered as the absence of violence (negative peace), however, one of the eminent peace scholars, Johan Galtung, who also introduced the concept of peace journalism, expanded the concept of peace. Accordingly, Johan Galtung (1969) introduced the concept of positive peace, which indicates the absence of structural and cultural violence other than the absence of direct violence (negative peace). In the real world, negative and positive peace is directly interconnected, which influences the culture of peace/violence as culture legitimizes either or both types of violence.

In this regard, peace journalism can be a useful tool to promote positive peace (but also culture of peace) since peace journalists "strive to spotlight individuals and initiatives that seek these harmonious conditions, and to lead constructive public dialogues about issues that pertain to justice and equity" (Youngblood, 2017). According to the peace journalists, they intend to frame their stories in a way to "give peace a chance" (Center for Global Peace Journalism, n/d). For that, the main objective of peace journalism is exploring the root causes of conflict for creating "opportunities for society at large to consider and value non-violent responses to conflict" (Lynch \& McGoldrick, 2005, p. 6).

Following that, the Center for Global Peace Journalism $(\mathrm{n} / \mathrm{d})$ shares ten elements describing peace journalism, which are:

1. PJ is proactive, examining the causes of conflict, and leading discussions about solutions.

2. PJ looks to unite parties, rather than divide them, and eschews oversimplified "us vs. them" and "good guy vs. bad guy" reporting.

3. Peace reporters reject official propaganda, and instead seek facts from all sources.

4. PJ is balanced, covering issues/suffering/peace proposals from all sides of a conflict.
5. PJ gives voice to the voiceless, instead of just reporting for and about elites and those in power.

6. Peace journalists provide depth and context, rather than just superficial and sensational "blow by blow" accounts of violence and conflict.

7. Peace journalists consider the consequences of their reporting.

8. Peace journalists carefully choose and analyze the words they use, understanding that carelessly selected words are often inflammatory.

9. Peace journalists thoughtfully select the images they use, understanding that they can misrepresent an event, exacerbate an already dire situation, and re-victimize those who have suffered.

10. Peace Journalists offer counter-narratives that debunk media created or perpetuated stereotypes, myths, and misperceptions.

The ten elements of peace journalism create the space to reflect the media's role, specifically in the case of nuclear power phase-out in South Korea. And, unfortunately, the news frames related to nuclear power phased-out produced by the main media show that they are not practicing peace journalism. Instead of examining the causes of conflict and leading discussions about the peaceful solution, the media become the cause of the conflict by producing propaganda that represents one side of the story. Most media give voice to the experts or elites more than the people who directly suffer from it, but the expert knowledge is often introduced at a superficial level rather than being used to provide depth and context of the topic. It ultimately highlights the importance of the media's role but also demonstrates the power of the media.

\section{CONCLUSION}

In the case of the nuclear power phase-out in South Korea, the peace journalism approach seems more than necessary since the conflict about the nuclear power phase-out has worsened as it has become a politicized matter. The energy transition is a necessary process in order to prevent climate change that threatens the wellbeing of human beings. However, as the article briefly explores the case of South Korea's policy for the energy transition, specifically the nuclear power phase-out, it involves different stakeholders (government, politicians from the oppo- 
sition party, nuclear power energy professionals and engineers, environmentalists, and the citizens who are directly affected by nuclear power energy projects). Furthermore, there are many scenarios that can be planned depending on what to value (e.g., economy or environment).

For that matter, the role of the media is extremely important, and the practice of peace journalism could represent a valuable contribution to decrease polarization and transform it into a constructive dialogue that helps policymakers and the different stakeholders, including individual citizens, to make informed decisions. In order to practice peace journalism, analyzing "how power operates" is essential (De Michelis, 2018 , p. 1). The media, in the case of nuclear phase-out, could make a valuable contribution by examining all the stakeholder's points of view, but furthermore understanding how all groups are interrelated so that the complex reality can be presented for the public to see and understand the bigger picture. This way, the mass media could play a meaningful role in helping peace to stand a chance.

\section{REFERENCIAS BIBLIOGRÁFICAS}

- Canning, D., \& Reinsborough, P. (2009). Re: imagining change - An introduction to story-based strategy.

https://www.patrickreinsborough.com/wpcontent/uploads/2017/02/smartMeme.ReImagini ngChangeIntroBooklet.pdf.

- Center for Global Peace Journalism. (n/d). Peace Journalism An Introduction. Park University. https://www.park.edu/wpcontent/uploads/2018/01/PJ-An-Introduction3.pdf.

- Ciftcioglu, V., \& Shaw, I.S. (2020). Peace journalism in times of 'war risks': Coverage of the hydrocarbons conflict in Turkish Cypriot and Greek Cypriot newspapers. The International Communication Gazette, O(0), 1-26. DOI: https://doi.org/10.1177/1748048520915668.

- Ciftcioglu, V. (2017). Peace Journalism: A Practical Handbook for Journalists in Cyprus. Peace Journalism.

http://www.peacejournalismcy.net/assets/peace_j ournalism_hand_book_2017.pdf.

- De Michelis, S. (2018). Peace Journalism in Theory and Practice. E-International Relations. https://www.e-ir.info/2018/12/23/peacejournalism-in-theory-and-practice/.
- Energy Transition Policy. (2020, March 11). Policy Briefing.

https://www.korea.kr/special/policyCurationView. do?newsId=148864795.

- Foucault, M. (1995). Discipline and Punish: The Birth of Prison. (A. Sheridan, Trans.) (2nd ed.). Vintage Books.

- Galtung, J., \& Lynch, J. (2010). Reporting Conflict: New Directions in Peace Journalism. University of Queensland Press.

- Galtung, J. (1969). Violence, peace and peace research. Journal of Peace Research, 6(3), 167-191. https://www.jstor.org/stable/422690.

- Hobbs, M. (2008, December). On Discourse and Representation: Reflection on Michel Foucalt's Contribution to the Study of the Mass Media. Annual Conference of the Australian Sociological Association University of Melbourne. Melbourne, Australia. https://nova.newcastle.edu.au/vital/access/servic es/Download/uon:6048/ATTACHMENT01.

- Kim, J.J. (2019). A Study on the News Frame about the Issues of the Social Conflicts: focused on the 'Nuclear-Exit' Policy of the Moon Jae-in Government [master's dissertation, Sungkyunkwan University]. http://dl.nanet.go.kr/law/SearchDetailView.do?cn =KDMT1201963932.

- Kim, D.K. (2020, September 15). 탈원전 논쟁, 제대로 이해하면 필요없다 [Nuclear power phaseout debate, it is not necessary if you understand it properly] Yeosijae Future Consensus Institute. https://bit.ly/3hZXV6F.

- Korea Energy Agency. (2019). 에너지 바로알기 [Understanding Energy Accurately]. http://www.energy.or.kr/web/kem_home_new/en ergy_issue/mail_vol116/pdf/2019_07_201902.pdf

- Lakoff, G. (2010). Why it Matters How We Frame the Environment. Environmental Communication, 4(1), 70-81. DOI: https://doi.org/10.1080/17524030903529749.

- Lee, S.H. (2018, July 4). '탈원전'이 말도 안 되는 13 가지 이유 [13 reasons why nuclear phase-out does not make sense]. New Daily. http://www.newdaily.co.kr/site/data/html/2018/ 07/04/2018070400111.html.

- Lynch, J. \& McGoldrick, A. (2005). Peace Journalism. Hawthorn Press.

- Schudson, M. (2003). The Sociology of News. Norton \& Company. 
- Yang, M.H., Lee, J.H., \& Kim, Y.S. (2015). 광복

70 년과 원자력 [70 Years of Independence and Nuclear Power]. Brief Report, 6, 1-19.

https://www.kaeri.re.kr/env/fileDownload?titleId $=5875 \&$ fileId $=1 \&$ fileDown Type $=$ C $\&$ param MenuId $=$ MENU00928.

- Youngblood, S. (2017, December 14). What is Peace Journalism? The Media and Peacebuilding Project.

https://mediapeaceproject.smpa.gwu.edu/2017/1

2/14/what-is-peace-journalism/ 